\title{
THE EFFECT OF CORPORATE GOVERNANCE, FIRM SIZE AND CAPITAL STRUCTURE ON FINANCIAL PERFORMANCE: A STUDY OF STATE-OWNED ENTERPRISES LISTED IN THE INDONESIA STOCK EXCHANGE DURING PERIOD OF 2013-2016
}

\author{
Firdaus Zuchruf*, Doctoral Candidate \\ Suhadak, Professor \\ Rahayu Sri Mangesti, Saifi Muhammad, Lecturers \\ Doctoral Program of Business Administration, Brawijaya University, Malang, Indonesia \\ *E-mail: zfyouse@gmail.com
}

\begin{abstract}
The purpose of this study is to examine and explain the effect of Corporate Governance, Firm Size and Capital Structure on Finacial Performance. This research is explanatory or confirmatory which provides a causal explanation or influence between variables through hypothesis testing. The data analysis method uses Generalized Structured Component Analysis (GSCA). The research findings show that Firm Size and Capital Structure have a positive and significant effect on Financial Performance. Corporate Governance variables have a positive and not significant effect on Financial Performance.
\end{abstract}

\section{KEY WORDS}

Corporate governance, firm size, capital structure, financial performance.

Corporate Governance is a system, process and set of regulations that are built to direct and control the company so as to create a good, fair and transparent relationship between stakeholders in the company. The implementation of consistent corporate governance will improve the quality of the company's financial statements. Management will tend not to manipulate financial statements, because there is a need to comply with various applicable accounting rules and principles and transparent presentation of information. Zarkasyi (2008) states that Corporate Governance is a means to make companies better, among others by inhibiting practices of corruption, collusion, nepotism, increasing budget discipline, utilizing supervision, and encouraging efficient management of the company.

Companies that implement Corporate Governance have good financial performance, this is because the company has implemented the principles of Corporate Governance namely transparency, accountability, fairness and responsibility. These principles make shareholders feel the positive impact of the trust that arises. This confidence arises due to the optimism of the shareholders towards the company so that the goals expected by the shareholders occur. Good management makes management work optimally so that optimal financial performance is achieved

Several empirical studies that have been conducted related to the effect of corporate governance with the company's financial performance as conducted by Nur'ainy et.al (2013) show that the application of corporate governance can directly influence company performance as measured by Economic Value Added, and also shows the effect indirectly through company size. Furthermore Fidanoski et al. (2013) in his study showed that only board size is positively related to bank profitability as measured by Return On Assets. Furthermore, research shows a negative relationship between board independence and Return on Assets and Return on Equity

Signaling Theory states how a company should give signals to users of financial and non-financial statements. Through this signal information can be found about the company's current and future conditions. Signals can be a comparison between the pros and cons of one company with another company. Signaling Theory also explains the effect of company size on financial performance. Large companies tend to distribute high dividends to maintain reputation among investors. According to Myers and Majluf (1977), companies would prefer to use debt to suppress the information asymmetry that can occur. In addition, according to 
the signaling theory, companies can communicate good growth prospects for the company in the future by using debt, therefore the better the size of the company, the signal will increase financial performance.

Firm size is a reflection of the size of the company's wealth. The greater the firm size, the greater the amount of company wealth that can be used to support its operational activities. If the company's operational activities run better, there will be more products produced so as to produce higher sales and higher profitability. Liargovas and Skandalis (2010) in their research found evidence that there was a positive relationship between company size and financial performance which was proxied by return on assets. Companies in large categories that are listed on the Indonesia Stock Exchange will obtain profits from their operations, in other words increasing the size of the company will increase the company's profitability.

The company's success in staying afloat and having good financial performance cannot be separated from the use of capital in its operational activities. Capital is a financial asset of a company that supports all the company's production activities. High and low capital structure of a company will reflect how the company's financial position. Companies are required to be able to create an optimal capital structure by collecting funds from within and outside the company efficiently, which means that company decisions must be able to minimize the cost of capital borne by the company or be able to maximize company profits.

The policies adopted by corporate finance managers in increasing profits, play an important role in corporate funding activities and are responsible for corporate finance and must be careful in making decisions, both in choosing the source of funding and financing budgeting. The selection of funding sources is very important for companies to find out the optimal balance of capital structure so that managers must be able to choose the right funding source for their company. Companies must be able to combine the use of internal funding sources and external funding sources that are most profitable in the selection of these funding sources.

Several empirical studies have shown evidence that capital structure influences financial performance as conducted by Mwangi et.al (2014), Ikapel \& Kajirwa (2017) that found evidence that financial leverage has a statistically significant negative relationship with performance as measured by return on assets and return on equity. Increased financial leverage has a negative effect on performance as measured by a company's return on equity

Referring to some previous research results and existing theories, this study seeks to develop a more representative model of each variable identified as a variable that has an influence on financial performance. Furthermore, the research aims to examine and explain the effect of Corporate Governance, Firm Size and Capital Structure on Financial Performance on State-Owned Enterprises listed on the Indonesia Stock Exchange

\section{THEORETICAL FRAMEWORK AND HYPOTHESIS}

Corporate Governance. Corporate governance deals with the ways in which all parties are interested in organizational well-being; efforts to ensure those leaders and other insiders take action or adopt mechanisms that protect the interests of stakeholders. Corporate governance refers to a set of rules and incentives where company management is directed and controlled (Velnampy, 2013).

According to the Cadbury Committee (1992) corporate governance is a system used by companies to mobilize and control company operations. In Corporate governance, the Board of directors is the part responsible for the implementation of Corporate Governance. Corporate governance is a principle that directs and controls the company in order to achieve a balance between the strength and authority of the company in providing accountability to shareholders in particular and stakeholders in general.

This study uses corporate governance in the form of the Proportion of Independent Commissioners and the Proportion of Independent Audit Committee, it is based that the Proportion of Independent Commissioners and the Proportion of Independent Audit 
Committee reflect or reflect the implementation of good corporate governance (Adi et al. (2012).

Firm Size. Firm size is a reflection of the size of the company's wealth. The greater the firm size, the greater the amount of company wealth that can be used to support its operational activities. The size of the company is a business scale of companies that can be grouped into three categories, namely small-scale businesses, medium-scale businesses and large-scale businesses. Companies that have gone public / listed on the IDX include companies that have large-scale businesses. Company size can be measured using total assets and total sales. The size of the company can have a positive effect on debt, because large companies have large assets that can be used as collateral if the company takes the debt. Barclay and Smith (1998) suggest that large companies when compared to small companies are able to bear large long-term debt, because they have the ability to pay loans and interest on loans.

Firm Size is a value that indicates the size of the company. Firm size is usually measured using total sales, total assets, and tangibility assets. The greater the value of total sales, total assets, and tangibility assets, the greater the size of the company. More detailed, the greater the total assets, the more capital invested, the more sales, the more money turnover and the greater tangibility of assets, the greater the company is known in the community (Sudarmadji and Sularto, 2009).

In this study Firm Size is measured using Total Assets / Log of total assets (Alipour et al. 2015, Najjar, 2011 and Dogan 2013), Total Sales / log of total sales (Salawu, 2012) and Tangibility Assets Ratio (Rajan and Zingales, 1995, Najjar and Petrov, 2011, Salawu 2012).

Capital Structure. Capital structure policy is a part of financing decision as the main decision in financial management besides investment decision and dividend decision or dividend policy. Funding decisions involve decisions relating to determining the best funding sources or capital structure. Financing corporate decisions is one of the financial strategic decisions related to how to obtain the funds and use of funds (Riyanto, 2001).

Weston \& Copeland (1992) state that financial structure refers to the way The Firm's assets are financed. Financial structure is represented by the entire right-hand side of The Balance Sheet. It includes short-term, debt and long-term debt as well as shareholder's equity. Capital structure or the capitalization of the firm is the permanen financing represented by long-term debt, preferred stock, and shareholder' equity. Thus, a firm's capital structure is only part of financial structure. The book value of shareholder's equity includes common stock, paid in or capital surplus, and the accumulated amount of retained earnings. If the firm has preferred stock, it is added to the shareholder's equity and the two together may be termed the firm's net worth.

Capital Structure variables are measured using three dimensions, namely Long term debt to total equity ratio (Abdul Rahman, 2017, Khanam et al, 2014), debt ratio (Adi et al. 2012) and debt to total equity ratio (Ebaid, 2009, Zeitun and Tian, 2007).

Financial Performnace. Financial performance is an illustration of the achievement of the company's success from various activities that have been carried out. It can be further explained that financial performance is an analysis carried out to see the extent to which a company has implemented financial rules properly and correctly, such as making a financial report that meets the standards and conditions in the General Accepted Accounting Principle (Fahmi, 2011).

Financial Performance in this study was measured by Return on Investment (Jacobson, 1987, Adi et al. 2013 and Dogan 2013), Return on Equity (Coleman, 2007; Zeitun and Tian, 2007, Ebaid, 2009, Adi et al. 2013, Pervan \& Visic, 2012, Mwangi et al. 2014) and Net Profit Margin (Zeitun and Tian 2007, Adi et al. 2013)

Pecking Order Theory. Myers \& Maljuf (1984) explained that the principle of pecking order theory is basically that companies prioritize internal funding sources. The company seeks to adjust its target dividend payout ratio to its investment opportunities; however, the company seeks to avoid drastically changing its dividend payments. A strict dividend policy coupled with fluctuations in profitability and unexpected investment opportunities, resulting in internal sources of funds (from the results of the company's operations), may exceed or even 
be less than the investment needs. Therefore, if the source of internal funds turns out to be smaller than the investment needs, the company will use cash balances or sell the portfolio of securities owned. If external funding is needed, the company will issue the most "secure" securities, first by issuing bonds, then followed by issuing securities that are characterized by options (such as convertible bonds). When this is deemed insufficient, the company will issue shares.

Furthermore, pecking order theory explains that if companies that borrow funds in small amounts, it is not because they have a low debt to equity ratio target, but because they require little external financing, as a consequence of the availability of sufficient internal funding sources. . Conversely for companies that are less profitable will tend to have greater debt for two reasons, namely insufficient internal funds and debt is the preferred source of external funds

According to Pecking Orfer Theory, external funds in the form of bond issuance take precedence over new shares. This is due to the cost of issuing new shares which is greater than the cost of issuing bonds. If a company issues risk-free debt, it certainly won't affect the value of existing shares. However, if the company issues risk-debt, the effect of the bond issuance will be smaller than the sensitivity of the information compared to the issuance of new shares.

Agency Theory. Jensen \& Meckling (1976) states agency relationships arise when one or more individuals (managers) hire other individuals (employees) to act on their behalf, delegating the power to make decisions to their employees. In the context of financial management, this relationship arises between: shareholders and managers and between shareholders and creditors.

Agency problems arise especially if it produces a very large free cash flow. Jensen \& Meckling (1976) defines free cash flow as cash flow that exceeds the funds needed for all projects that have a positive net present value after being discounted at the cost of capital. Existence of too much free cash flow can lead to discretion that deviates from the manager's behavior, namely actions and decisions that do not fully reflect the interests of shareholders

The emergence of agency problems that originate from conflicts of various parties, so to minimize the conflict in an effort to overcome agency problems, a supervisory mechanism is needed to ensure that managers will act on the best decision for all parties. This oversight mechanism consequently results in costs known as agency costs which include: expenses to monitor manager's activities, expenses to create an organizational structure that minimizes undesirable manager's actions, and opportunity costs arising from the condition of managers not being able to immediately make decisions without shareholder approval (Jensen \& Mecking, 1976).

Modigliani Miller Theory. Modigliani \& Miller (1963) argue in proposition I, that the value of each company is a capitalization of expected net operating income or expected net operating income with a constant capitalization level that is consistent with the level of risk of the company. The required level of profit and the company's value for which one hundred percent of capital consists of own capital or an unlevered firm. According to Modigliani \& Miller, the value of a company does not depend or is not influenced by capital structure (Sartono, 1996)

In proposition II, Modigliani \& Miller argues that the cost of the company's own capital that has leverage is the same as the cost of the company's own capital that has no leverage plus risk premium. The size of the risk premium depends on the difference between the cost of own capital and the cost of corporate debt that has leverage multiplied by the amount of debt without calculating taxes or in no tax conditions.

Corporate Governance helps create a conducive and accountable relationship between the inside of the company (the Board of Commissioners, the Board of Directors, and shareholders) in order to improve company performance. In this paradigm, the Board of Commissioners is in a position to ensure that management has truly worked for the interests of the company according to established strategies and safeguards the interests of shareholders, namely to increase the economic value of the company. Likewise, the Audit Committee has a very important and strategic role in maintaining the credibility of the 
process of preparing financial statements as well as maintaining the creation of an adequate corporate supervision system and the implementation of Corporate Governance. An independent board of commissioners has better supervision over management, thereby reducing the possibility of fraud in presenting the financial statements. The Independent Commissioner of a company must be truly independent and be able to reject the influence, intervention and pressure of the major shareholders who have a public interest in certain transactions or interests.

Okiro et.al (2015) in his study found evidence that there was a significant positive influence between corporate governance on company performance. This study also confirms that there is a significant positive relationship between the effect of intervening capital structure (leverage) on the influence between corporate governance on company performance.

High and low financial performance of one company is influenced by the size of the company. According to Ferry and Jones (in Sujianto, 2001) the size of the company describes the size of a company as indicated by total assets, total sales, average total sales and average total assets. The size of the company is also an important factor that determines the company's financial performance. This is evidenced by the company's ability to generate profits. Because the larger the company, the greater the company's ability to deal with business problems and the company's ability to generate high profits because it is supported by large company assets so that company constraints such as the lack of adequate equipment and the like can be overcome (Sambhara Kreshna, 2010).

Liargovas and Skandalis (2010) in their research found evidence that there is a positive relationship between company size and financial performance which is proxied by return on assets. Companies in large categories that are listed in Indonesia will obtain profits from their operations, in other words, increasing the size of the company will increase the profitability of the company

Capital structure is one of the factors that greatly influences the establishment of a company, where the operational activities of a company are due to the funds owned by the company. With the funds, companies can buy materials that will be produced and produce products and then marketed to the public. Usually the company uses funds from equity if the company is able to use these funds, if by using equity it is deemed insufficient, the company uses debt as funds to run its operations. In running the company's operations, all managers must expect to get the maximum profit. With the benefits, the company will survive and have competitiveness in the future.

The capital structure of a company is used to determine the company's financial performance. The company's capital structure is a combination of different shares (common stock and preferred stock) or a mix of all long-term funding sources (equity and debt) used. The optimal capital structure is the company's capital structure that will maximize its stock price. Too much debt can hinder the development of a company that will make shareholders think twice about continuing to invest (Joni and Lina, 2010).

Mwangi et al. (2014) examined the relationship of capital structure with the company's financial performance measured by ROA and ROE. The results showed that financial leverage has a statistically significant negative relationship with performance as measured by return on assets (ROA) and return on equity (ROE). Increased financial leverage has a negative effect on performance as measured by ROE from non-financial companies listed on NSE, Kenya

This study is a development of the results of previous studies related to variables that are determinants of the interaction of corporate governance, firm size, capital structure decisions with the company's financial performance. This research model is built on the basis of developing previous research models based on the evolution of previous research models related to the variables studied. From the description above it can be described the conceptual model in this study as shown in figure 1.

Based on the framework, the hypothesis is as follows. Corporate governance is a concept that emphasizes the importance of the rights of shareholders to obtain accurate, correct and timely information. It also shows the company's obligation to disclose all financial 
information, company performance accurately, timely and transparently. Corporate governance requires parties or groups to monitor the implementation of directors' policies, therefore the board of commissioners is a central part of the corporate governance mechanism. The board of commissioners plays an important role in directing the strategy and overseeing the running of the company and ensuring that managers really improve the company's performance as part of achieving the company's goals. The greater or more dominant number of independent directors will be able to give power to the board of commissioners to pressure management to improve the company's financial performance. In other words, the greater composition of independent commissioners can encourage the board of commissioners to act objectively and be able to protect all company stakeholders.

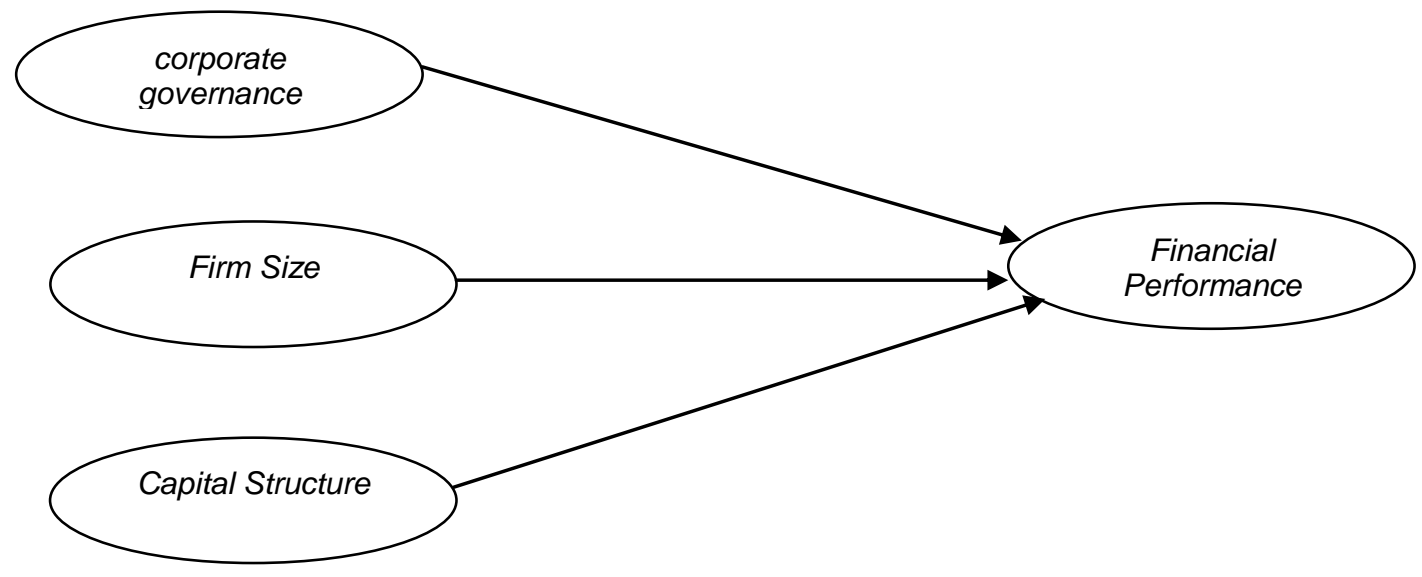

Figure 1 - Framework of Thinking

Xie et al. (2003) explain that the effectiveness of audit committees in reducing earnings management is done by management. The results obtained from this study in the form of a conclusion that the audit committee originating from outside is able to protect the interests of shareholders from earnings management actions taken by management. The effect on managed accruals is shown by the more frequent audit committees meet and the effect is indicated by a significant negative coefficient. The audit committee has an important and strategic role in terms of maintaining the credibility of the financial statement preparation process as well as maintaining the creation of an adequate corporate supervision system and the implementation of Corporate governance. With the audit committee functioning effectively, the control of the company will be better, so that agency conflicts that occur due to the desire of management to improve their own welfare can be minimized.

Empirical studies that investigate the relationship between corporate governance and financial performance. has been done by Nur'ainy et al. (2013) found evidence that the implementation of corporate governance can directly influence company performance as measured by Economic Value Addes, and also shows indirect effects through company size. Furthermore Okiro et al. (2015) and Adi et al. (2012) shows evidence that there is a positive causal relationship between corporate governance and company performance.

$\mathrm{H}_{1}$ : Corporate governance has a significant effect on financial performance.

One measure that shows the scale of the company is the size of the company. Determination of company size can be stated by total assets. Company size factor is an important factor in the formation of profits. Large companies that are considered to have reached maturity indicate that the company is relatively more stable and more capable of generating profits than small companies. With the large resources, the company can invest both current assets and fixed assets, so that they can produce products according to market demand and expand market share. With the increasing sales, the company can cover costs that come out during the production process, so the company's profits will increase.

Companies with large total assets reflect the reliability of the company. The large size of the company is expected to increase economies of scale and reduce the costs of 
information gathering and processing. Sudarmadji and Sularto (2007) stated that large companies that have large resources will be easy to go to the capital market. Ease of dealing with the capital market means having greater flexibility and a greater level of investor confidence because it has greater operational performance. Large companies are able to attract greater investor interest than smaller companies because they have better investment placement flexibility.

An empirical study examining the effect of company size on financial performance has been carried out by Pervan \& Visic (2012) which shows that company size has a positive (though weak) significant effect on firm profitability. In addition, the results show that asset turnover and debt ratios also statistically have a significant effect on company performance. Liargovas and Skandalis (2010) in their research found a positive relationship between company size and financial performance which is proxied by return on assets.

$\mathrm{H}_{2}$ : Firm Size has a significant effect on financial performance.

Capital structure decisions will affect financial performance and vice versa. The level of use of debt at a certain point (the optimal limit) in capital structure decisions will have a positive effect on the company's financial performance because the amount of profit available to shareholders has increased due to tax savings due to debt use, but the greater the proportion of debt (exceeds the optimal limit) which is used in the capital structure, the greater the fixed obligation in the form of debt and interest installments paid by the company so that the amount of profit available to shareholders will decrease

Capital structure theory has several different views regarding the effect of debt levels on firm performance. The trade off theory explains that the level of debt has a positive effect on company performance. Debt funding is expected to increase the company's production capacity and can provide tax-saving benefits. In contrast, the pecking order theory explains that the level of debt negatively affects a company's performance due to the accompanying risks.

Long-term debt has benefits and also greater risks compared to short-term debt. Long repayment deadlines allow companies the leeway to utilize these funding sources to generate more profits. Thus, long-term debt can improve company performance. But on the other hand, long-term debt has a relatively higher interest rate. High interest rates can cause companies to experience difficulties in repayment, thereby increasing the likelihood of financial difficulties. If it happens continuously, this can result in bankruptcy.

Empirical studies examining the influence of capital structure decisions on financial performance have been conducted by several researchers such as Khan et al. (2013) who found evidence of Long Debt to Assets, and Debt Asstes Ratio had a negative and significant effect on Return on Assets, and Debt Assets Ratio have a negative and not significant effect on Return on Equity. Khanam et al. (2014) found evidence that Debt Assets Ratio had a negative and significant effect on Return on Assets, Debt Assets Ratio had a positive and significant effect on Net Profit Margin, and Debt Assets Ratio had a negative and not significant effect on Return on Equity and Earning per Share.

$\mathrm{H}_{3}$ : Capital Structure has a significant effect on financial performance.

\section{METHODS OF RESEARCH}

This study uses a quantitative approach to the type of research explanatory research with the purpose of explanation (explanatory or confirmatory) which provides causal explanation or influence between variables through hypothesis testing. The population in this study is all State-Owned Enterprises listed on the Indonesia Stock Exchange. The total number of issuers is 16 , using data from four years of financial statements.

Financial Performance is the financial condition of a company that is analyzed with financial analysis tools, so that it can be known about the highs and lows and goods of the company's financial condition that shows work performance in a certain period.

The steps in the GeSCA are as follows (Solimun, 2013): Designing a Structural Model (relationship between latent variables); Designing a Measurement Model; Constructing the Path diagram. 
Table 1 - Hypotheses, Previous theoretical and research references in the Concept Model

\begin{tabular}{|c|l|l|}
\hline H & \multicolumn{1}{|c|}{ Hypothesis } & \multicolumn{1}{c|}{ Reference } \\
\hline H1 & $\begin{array}{l}\text { Corporate Governance has a significant effect on } \\
\text { Financial Performance }\end{array}$ & $\begin{array}{l}\text { Nur'ainy et.al (2013), Okiro et al. (2015) Adi et al. } \\
\text { (2013), Xie et al. (2003). }\end{array}$ \\
\hline H2 & $\begin{array}{l}\text { Firm Size has a significant effect on Financial } \\
\text { Performance }\end{array}$ & $\begin{array}{l}\text { Pervan \& Visic (2012), Liargovas and Skandalis } \\
(2010)\end{array}$ \\
\hline H3 & $\begin{array}{l}\text { Capital Structure has a significant effect on } \\
\text { Financial Performance }\end{array}$ & Khan et al. (2013), Khanam et al. (2014 \\
\hline
\end{tabular}

Source: Data processed by the author.

Table 2 - Measurement of Financial Performance

\begin{tabular}{|c|c|c|c|}
\hline No & Variable & Indicator & Measurement \\
\hline \multirow{2}{*}{1} & Financial Performance & Return On Investment & $\begin{array}{r}\text { ROI }=\frac{\text { Earning After Tax }}{\text { Total Assets }} \\
\text { (Jacobson (1987)) }\end{array}$ \\
\cline { 3 - 4 } & Return on Equity & $\begin{array}{c}\text { ROE }=\frac{\text { Earning Before Tax }}{\text { Totall Equity }} \\
\text { (Coleman,2007) }\end{array}$ \\
\cline { 3 - 4 } & Net Profit Margin & $\begin{array}{c}\text { NPM }=\frac{\text { Net Profit }}{\text { Total Sales }} \\
\text { (Zeitun and Tian, 2007) }\end{array}$ \\
\hline
\end{tabular}

Source: Data processed by the author.

Table 3 - Measurement of Independent Variables

\begin{tabular}{|c|c|c|c|}
\hline No & Variable & Indicator & Measurement \\
\hline \multirow{2}{*}{1} & \multirow{2}{*}{$\begin{array}{l}\text { Corporate } \\
\text { Governance }\end{array}$} & $\begin{array}{c}\text { Proportion of Independent Commissioners } \\
\text { (Percentage of independent directors on the board } \\
\text { of commissioners) }\end{array}$ & $I C=\frac{\text { Number of Independent Commissioners }}{\text { Total Number of Board of Commissioners }}$ \\
\hline & & $\begin{array}{c}\text { Proportion of Independent Audit Committee } \\
\text { (Percentage of Independent Audits on the audit } \\
\text { board) }\end{array}$ & $I A C=\frac{\text { Number of Independent Audits }}{\text { Total Number of Audit Committees }}$ \\
\hline \multirow{3}{*}{2} & \multirow{3}{*}{ Firm Size } & Total Assets & $\begin{array}{l}\text { Natural logarithm of total assets } \\
\text { (Alipour et al,2015) }\end{array}$ \\
\hline & & Total Sales & $\begin{array}{l}\text { Natural logarithm of total sales } \\
\text { (Salawu, 2012)) }\end{array}$ \\
\hline & & Tangibility Assets & $\begin{aligned} T A & =\frac{\text { Fixed Assets }}{\text { Total Assets }} \\
& (\text { Najjar and Petrov, 2011) }\end{aligned}$ \\
\hline \multirow{3}{*}{3} & \multirow{3}{*}{$\begin{array}{l}\text { Capital } \\
\text { Structure }\end{array}$} & Debt Assets ratio & $\begin{array}{l}D A R=\frac{\text { Total Debt }}{\text { Total Assets }} \\
\text { (Adi et al. (2012)) }\end{array}$ \\
\hline & & Debt to Equity Ratio & $\begin{array}{c}D E R=\frac{\text { Total Debt }}{\text { Total Equity }} \\
\text { (Adi et al. (2012) }\end{array}$ \\
\hline & & Long Term Debt to Total Equity ratio & $\begin{array}{l}\text { LTDTE }=\frac{\text { Long term Debt }}{\text { Total Equity }} \\
\text { (Khanam et al.,2014) }\end{array}$ \\
\hline
\end{tabular}

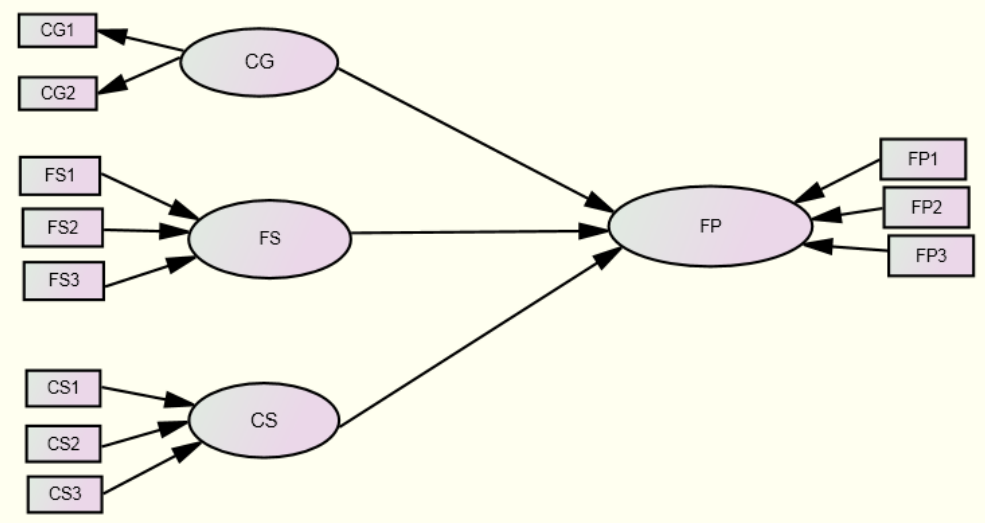

Figure 2 - Research Analysis Model 
Figure 2 Descriptions:

- CG: Corporate Governance;

- CG1: Proportion of Independent Commissioners;

- CG2: Proportion of Independent Audit Committee;

- FS: Firm Size;

- FS1: Total Assets;

- FS2: Total Sales;

- FS3: Tangibility Assets;

- CS: Capital Structure;

- CS1: Debt Assets Ratio;

- CS2: Debt to Equity Ratio;

- CS3: Long Term Debt to Total Equity Ratio;

- FP: Financial Performance;

- FP1: Return on Investment;

- FP2: Return on Equity;

- FP3: Net Profit Margin.

\section{RESULTS AND DISCUSSION}

Overall Model Testing Results that involve measurement models and structural models based on GSCA calculations and significant tests obtained through Boststrapping are presented in table 4:

Table 4 - Testing of Fit Models

\begin{tabular}{|c|c|}
\hline & Model Fit \\
\hline FIT & 0.470 \\
\hline AFIT & 0.455 \\
\hline
\end{tabular}

The results of the analysis obtained a FIT value of 0.470 , this means that the model formed is able to explain all the existing variables by $47 \%$. AFIT value $=0.455$ shows the diversity of Corporate Governance, Firm Size, and Capital Structural variables towards Financial Performance can be explained by the model after experiencing a correction of 45.5 $1 \%$. Hypothesis testing in the GSCA analysis is based on the estimated value and significance between variables. The test results are presented in the following table:

Table 5 - Results of Hypothesis Testing Analysis

\begin{tabular}{|c|c|c|c|c|c|}
\hline \multirow{2}{*}{ No } & \multicolumn{2}{|c|}{ Relationship between Variables } & Estimate & CR & explanation \\
\hline 1 & Corporate Governance & Financial Performance & 0.042 & 0.47 & Non Significant \\
\hline 2 & Firm Size & Financial Performance & 0.444 & 3.34 & Significant \\
\hline 3 & Capital Structure & Financial Performance & -1.046 & 14.97 & Significant \\
\hline
\end{tabular}

Description: *= Significant at $\alpha=0.05$.

Hypothesis analysis results:

- Hypothesis 1: Corporate Governance has no significant effect on Financial Performance. The GSCA test results show that the estimated path coefficient of 0.042 and $C R$ of 0.47 is smaller than the 1.98 table, at the level of $P=0.05$. Empirical test results are not enough evidence to accept hypothesis 1 . Significantly positive path coefficient can be interpreted that between Corporate Governance and Financial performance has a direct effect. The influence of Corporate Governance on Financial Performance is not in accordance with the initial prediction that Corporate Governance has a significant effect on Financial Performance. These results indicate that Corporate Governance is not a determining factor for Financial Performance; 
- Hypothesis 2: Firm Size has significant effect on Financial Performance. The GSCA test results show that the estimated path coefficient of 0.444 and CR of 3.34 is greater than the 1.98 table, at the level of $P=0.05$. Empirical test results are sufficient evidence to accept hypothesis 2 . Significantly positive path coefficients can be interpreted that between Firm Size and Financial performance has a direct effect. The influence of Firm Size on Financial Performance is in accordance with the initial prediction that Firm Size has a significant effect on Financial Performance. These results indicate that Firm Size is a determinant of Financial Performance;

- Hypothesis 3: Capital Structure has significant effect on Financial Performance. The GSCA test results show that the estimated path coefficient of -1.046 and CR 17.97 is greater than the 1.98 table, at the level of $P=0.05$. Empirical test results are sufficient evidence to accept hypothesis 3 . Significantly negative path coefficients can be interpreted that between Capital Structure and Financial Performance has a nondirectional effect. The effect of Capital Structure on Financial is in accordance with the initial prediction that Capital Structure has a significant effect on Financial Performance. These results indicate that Capital Structure is a determining factor for financial performance.

\section{DISCUSSION OF RESULTS}

The Corporate Governance variable has no significant effect on Financial Performance. This finding is not in accordance with the hypothesis prediction $(\mathrm{H} 1)$ which predicts that corporate governance has a significant effect on Financial Performance. The meaning of this finding shows that empirically Corporate Governance is not always or not a determining factor in its influence on Financial Performance on State-Owned Enterprises listed on the Indonesia Stock Exchange. This finding also indicates that Financial Performance in StateOwned Enterprises listed on the Indonesia Stock Exchange is not always determined by the variables of the Proportion of Independent Commissioners and the Proportion of Independent Audit Committee.

The direction of the positive and insignificant Corporate Governance path coefficient supports the results of Noordin \& Salina's (2011) research which shows evidence that Corporate Governance has no significant effect on Financial Performance. The research findings show that independent commissioners have no effect on the company's financial performance, as evidenced by the low proportion of independent commissioners in StateOwned Enterprises, the existence of the number of independent directors is only able to contribute a little in the oversight function to the company's performance so that the function of independent directors in supervising company performance be less than optimal.

The research findings show that the independent audit committee has no effect on the company's financial performance, this is due to the low proportion of the independent StateOwned Enterprises audit committee. Audit committees that are almost the same in every sample company that has different company complexity are considered less effective, so it does not have a significant impact on company performance. The complexity of the company can be seen from the number of subsidiaries owned by each company.

Based on the regulation of the Financial Services Authority Number 55 / POJK.04.2015 that is the minimum number of audit committees is $30 \%$. Based on research data at each State-Owned Enterprises that the average number of Audit Committees only meets the specified criteria. This can be explained that the greater Audit committee enables better reporting quality and higher monitoring of management because the more effective audit committee supervision will optimize the company's financial performance.

Firm size variables have a significant effect on Financial Performance. This finding is consistent with the hypothesis prediction $(\mathrm{H} 2)$ which predicts that firm size has a significant effect on Financial Performance. The meaning of this finding shows that firm size is always empirically or is a determining factor in its influence on Financial Performance in StateOwned Enterprises listed on the Indonesia Stock Exchange. This finding also indicates that 
Financial Performance in State-Owned Enterprises listed on the Indonesia Stock Exchange is always determined by indicators of Total Assets, Total Sales and Tangibility Assets.

The direction of the Firm Size path coefficient that is positive and significant is in line with research by Liargovas and Skandalis (2010) in their research finding evidence of a positive relationship between company size and financial performance which is proxied by return on assets. Companies in large categories that are listed in Indonesia will obtain profits from their operations, in other words, increasing the size of the company will increase the profitability of the company. Dogan (2013) states that the use of total assets and total sales as firm size measurements has a positive effect on Return on Asstes. The size of the company shows an increase in assets in each company. In theory, increasing company size will increase the company's financial performance

Financial performance is the success of a company's business that can be assessed in terms of money in this case operating income expressed in rupiah units. This financial performance is influenced by assets used in the company's operations, both current assets and fixed assets. Current assets such as cash, receivables, banks, inventories and others that revolve normally and return optimal returns to the company. In addition, non-current assets can also provide the function of assets by suppressing excessive expenditure levels, if assets operate smoothly or not smoothly operating normally in the organizational cycle, it can ultimately affect financial performance.

Furthermore Salawu (2012) states that total sales affect financial performance. The higher sales will increase the company's chances of maximizing profits, if this can be maintained well by the company then profit growth will be stable. Good profit growth in a company will increase opportunities in improving company performance. The high sales also indicate the high scale of a company's production so that it can increase the company's opportunities in improving financial performance. The better the company in generating sales based on assets owned, it will affect the level of profits derived by the company. Profitability is the level of the company's ability to generate profits or profits based on assets owned by the company.

Capital Structure variable has a significant negative effect on Financial Performance. This finding is in accordance with the hypothesis prediction $(\mathrm{H} 3)$ which predicts that the Capital Structure has a significant effect on Financial Performance. The meaning of this finding shows that empirically Capital Structure is inversely proportional to Financial Performance in State-Owned Enterprises listed on the Indonesia Stock Exchange.

Significant negative effect of Capital structure variable on Financial Performance is due to several sample companies of capital structure indicators such as Debt to Assets ratio, debt to equity ratio and Long term debt to equity ratio have increased in several years while the financial performance shown by Return on Investment (ROI) ), Return on Equity (ROE) and Net Profit Margin (NPM) have decreasedHasil penelitian ini sejalan dengan penelitian Khan et al. (2013) yang menganalisis pengaruh struktur modal terhadap kinerja keuangan perusahaan mesin di Pakistan menemukan bukti bahwa DAR berpengaruh negatif and signifikan terhadap ROA. Arah koefisien path yang negatif ini mengindikasikan bahwa secara empiris meningkatnya proporsi penggunaan total hutang dalam struktur modal akan menurunkan kinerja keuangan (ROI, ROE).

The results of this study differ from funding theory (Modigliani \& Miller, 1963) which states that funding from debt will improve the company's financial performance due to tax savings from interest payments. Capital structure decisions will affect the company's financial performance. The increasing level of debt usage at a certain point (optimal limit) in capital structure decisions will have a positive effect on the company's financial performance because the amount of profit available to shareholders has increased due to tax savings due to the use of debt, but the greater the proportion of debt used in the structure capital will also increase the fixed liability in the form of debt and interest installment payments borne by the company so that the amount of profit available to shareholders will decrease. Therefore, the effect of capital structure on financial performance can be positive and can be negative

A negative effect can be interpreted that the higher the Debt to Asset ratio, the greater the financial risk. The increased risk in question is the possibility of default (default) because 
the company is too much funding of assets from debt. With the risk of default, the costs that must be incurred by the company to overcome this problem is even greater. The lower the Debt to Asset Ratio, the higher the company's ability to pay all its obligations, which means that only a small portion of the company's assets are financed by debt.

According to Horne \& Wachowisz (2009), the higher the Debt to Asset Ratio, the greater the financial risk. The increased risk in question is the possibility of default (failure to pay) because the company is too much funding assets from debt. Based on the Pecking Order Theory, the greater this ratio indicates that the greater the costs that must be borne by the company to meet the debt that must be paid

\section{CONCLUSION}

Corporate Governance as measured by the Proportion of Independent Commissioners and the Proportion of Independent Audit Committee has an insignificant influence on Financial Performance. This finding is not in line with the Signaling Theory (Myers \& Majluf 1984), which is giving meaning to company conditions based on the views of outside parties. The better the Corporate Governance, the better the positive signal the better the company's financial performance. This finding indicates that Corporate Governance is not empirically a determining factor in Finacial Performance in State-Owned Enterprises listed on the Indonesia Stock Exchange (IDX).

Firm Size as measured by Total assets, Total Sales and Tangibility assets has a significant effect on Financial performance. This finding is in line with signaling theory where according to Myers and Majluf (1977), companies would prefer to use debt to suppress the information asymmetry that can occur. In addition, according to signaling theory, companies can communicate good growth prospects for companies in the future by using debt, therefore the better the size of the company, the signal will increase financial performance. This finding indicates that Firm size is empirically a determining factor for Financial Performance in StateOwned Enterprises listing on the Indonesia Stock Exchange (IDX).

Capital structure variable has a significant and negative effect on Financial performance. The findings differ from the theory of funding decisions (Modigliani \& Miller, 1963) which states that funding from debt will improve the company's financial performance due to tax savings from interest payments.

\section{RECOMMENDATIONS}

The results of this study indicate that Corporate Governance variables measured by the Proportion of Independent Commissioners and the Proportion of Independent Audit Committee have insignificant influence on the Capital structure and Financial Performance. This insignificant influence of Corporate Governance occurs because of the low number of independent commissioners, the adoption of Corporate Governance is only as a fulfillment of the standards set by the Financial Services Authority. Based on the results of this study, the advice that can be given to State-Owned Enterprises and the Government is the need to reduce and eliminate the confusion between business interests and the interests of the government and other state institutions in State-Owned Enterprises, and reduce government intervention in various business decisions in the State -Owned Enterprises

Recommendations for future development of this research related to the substance of the study are (1) adding indicators of other factors such as political connections that play a role in CG in State-Owned Enterprises (2) adding other variables that affect capital structure and financial performance in the research model so that it will produce a more comprehensive research model, and (3) confirm the results of this research in the future.

\section{REFERENCES}

1. Abdul Rahman, A. A. A. (2017). The Relationship between Solvency Ratios and Profitability Ratios: Analytical Study in Food Industrial Companies listed in Amman Bursa. 
International Journal of Economics and Financial Issues, 7(2), 86-93.

2. Adi TW, Suhadak, Handayani SR, Rahayu SM. 2013. The Influence of Corporate Governance and Capital Structure on Risk, Financial Performance and Firm Value: A Study on the Mining Company Listed in Indonesia Stock Exchange in 2009-2012. European Journal of Business and Management. Vol.5, No.29,200-217.

3. Al-Maghzom, A, Hussainey, K \& Aly, D. 2016. Corporate Governance and Risk Disclosure: Evidence from Saudi Arabia. RG Journal Impact 13(2):145-166.

4. Alipour, M., Mohammadi, M.F.S \& Derakhshan, H. 2015. International Journal of Law and Management. Vol. 57 No. 1, 2015 pp. 53-83.

5. Barclay, Michael. J., Clifford W. Smith Jr., Ross L Watts. 1998, "The Determinations of Corporate Leverage and Dividend Policies, dalam The New Corporate Finance, 1999, two edition., Irwin Mc Graw-Hill, Malaysia.

6. Cadbury Report. (1992). Report of Committee on The Financial Aspects of Corporate Governance. Great Britain: Gee.

7. Coleman, Anthony Kyereboah. 2007. Corporate Governance and Firm Peformance In Africa - A Dynamic Panel, A Papaer Preapared for the "International Confrence on Corporate Governance in Emerging Markets", Organized by the Global Corporate Governance Forum (GCGF) and Asian Institute of Corporate Governance (AICG). 15th 17th November, 2007, Sabanci University, Istanbul, Turkey.

8. Doğan, M. 2013. Does Firm Size Affect The Firm Profitability? Evidence from Turkey. Research Journal of Finance and Accounting, 4(4), 53-60.

9. Ebaid Ibrahim El-Sayed. 2009. The impact of capital structure choice on firm performance: empirical evidence from Egypt, Journal of Risk Finance, Them Vol, 10. Iss: 5, pp. 477-487.

10. Fahmi Irham. (2011). ANALISIS KINERJA KEUANGAN Panduan bagi Akademisi, Manajer, and Investor untuk menilai and Menganalisis Bisnis dari Aspek Keuangan, Alfabeta CV. Bandung.

11. Fidanoski, F., \& Mateska, V., \& Simeonovski, K. 2013.Corporate Governance and Bank Performance: Evidence from Macedonia. MPRA Paper 46773.University Library of Munich. Germany.

12. Horne, V.J.C \& Wachowisz, J.M 2009. Prinsip-prinsip Manajemen Keuangan. Edisi Indonesia. Salemba Empat. Jakarta.

13. Ikapel, O. F. \& Kajirwa, I. 2017. Analysis of long term debt and financial performance of state owned sugar firms in Kenya. International Journal of Commerce and Management Research, 3(2), 108-111.

14. Jacobson, Robert. 1987. The Validity of ROI as a Measure of Business Performance, The American Economic Review, Vol. 77, No. 3 (Jun., 1987), pp. 470-478Published by: American Economic Association.

15. Jensen, Michael C. and Meckling, William H. 1976.Theory of the Firm: Managerial Behaviour, Agency Costs, and Ownership Structure, Journal of Financial Economics, 3, 305-350.

16. Joni and Lina. 2010. Faktor-faktor yang Mempengaruhi Struktur Modal. Jurnal Bisnis and Akuntansi, Vol 12(2): Pp.81-96.

17. Khan, F.N., Niazi, G.S.K \& Akram, T. 2013. Impact of Capital Structure on Firm Financial Performance: A Case Of The Pakistani Engineering Firms Listed On KSE. International Journal of Information, Business and Management, Vol. 5, No.2,pp. 218-240.

18. Khanam, F., Nasreen, S \& Pirzada S.S. 2014. Impact of Capital Structure on Firm's Financial Performance: Evidence from Food Sector of Pakistan. Research Journal of Finance and Accounting. Vol.5, No.11, 2014. p 93.104.

19. Liargovas, Panagiotis G and Konstantinos S. Skandalis. 2010. "Factors Affecting Firm's Performance: The Case of Greece". Journal of Global Business and Management Research, Vol. 2, No. 2 \& 3; 184-197.

20. Mwangi et.al (2014), Mwangi, L. W., Makau, M. S., \& Kosimbei, G. (2014). Relationship between Capital Structure and Performance of Non- Financial Companies Listed in the Nairobi Securities Exchange, Kenya. Global Journal of Contemporary Research in 
Accounting, Auditing and Business Ethics (GJCRA), 1(2), 72-90.

21. Myers, Stewart C. and Majluf, Nicholas S. 1984.Corporate financing and investment decisions when firms have information that investors do not have. Journal of Financial Economics 13 (2): 187-221.

22. Modigliani, F., \& Miller, M. H. 1963. Corporate Income Taxes and the Cost of Capital: A Correction. The American Economic Review, 53(3), 433-443.

23. Najjar, N and Petrov, K. 2011. Capital Structure of Insurance Companies in Bahrain. International Journal of Business and Management Vol. 6, No. 11; p. 138-145.

24. Noordin, N.H \& Salina, K. 2011. Corporate Governance and Financial Performance: Empirical Evidence from Public Listed Construction Companies in Malaysia.

25. Nur'ainy, R., Bagus, N.B., Kurniasih, A.S and Sugiharti, B. 2013. Implementation of Good Corporate Governance and Its Impact on Corporate Performance: The MediationRole of Firm Size (Empirical Study from Indonesia), Indonesia. Global Business and Management Research: An International Journal Vol. 5, Nos. 2 \& 3.

26. Okiro, K., Aduda, J., \& Omoro, N. (2015). The Effect of Corporate Governance and Capital Structure on Performance of Firms Listed at the East African Community Securities Exchange. European Scientific Journal, 11(7), 504-533.

27. Pervan, $M$ \& Visic, 2012. Influence of firm size on its business success. Croatian Operational Research Review (CRORR), Vol. 3,213-223.

28. Rajan and Zingales, 1995 Rajan, Raghuram G. and Zingales, Luigi. 1995, What Do We about Capital Structure? Some Evidence from International Data. The Journal Finance, Vol. 50 No. 5 (Dec., 1995), pp. 1421-1460.

29. Riyanto, Bambang. 2001. Dasar-Dasar Pembelanjaan Perusahaan. : BPFE Yogyakarta

30. Sambharakreshna, Yudhanta. 2010. Pengaruh Size of Firm, Growth and Profitabilitas Terhadap Struktur Modal Perusahaan." Jurnal Akuntansi, Manajemen Bisnis and Sektor Publik. JAMBSP Vol. 6 no.2, Februari 2010: 197-216.

31. Sartono, R.A. 1996. Manajemen Keuangan: Teori and Aplikasi.Edisi 4, BPFE-, Yogyakarta.

32. Salawu, R.O., Asaolu, T.U \& Yinusa, D.O. 2012 Financial Policy and Corporate Performance: An Empirical Analysis of Nigerian Listed Companies. International Journal of Economics and Finance. Vol. 4, No. 4; 175-181.

33. Sudarmadji and Sularto. 2009. Pengaruh Struktur Aktiva, Ukuran, Likuiditas, and Profitabilitas Terhadap Struktur Modal Emiten Sektor Ritel Di Bursa Efek Indonesia: Sebuah Pengujian Hipotesis Pecking Order. Jurnal IImiah Akuntansi Universitas Kristen Maranatha, Nomor 1, volume 9, pp. 71-84.

34. Sujianto, A.E. 2001. Analisis Variabel -Variabel Yang Mempengaruhi Struktur Keuangan Pada Perusahaan Manufaktur Yang Go Public di Bursa Efek Jakarta. Jurnal Ekonomi and Manajemen. Vol.2. No.2.

35. Velnampy T 2013. Corporate Governance and Firm Performance: A Study of Sri Lanka Manufacturing Companies Journal of Economics and Sustainable Development, Vol 4, No 3.

36. Copeland, Thomas E., and Weston, J. Fred. 1992. Manajemen Keuangan. Edisi Kedelapan. Jakarta : Erlangga.

37. Xie, Biao, Wellace N Davidson and Peter J. Dadalt, 2003, "Earnings Management Corporate Governance: The Roles Of The Board and The Audit Committee", Jurnal of Corporate Finance, Vol,9. pp. 295-316.

38. Zarkasyi, Wahyudin. 2008. Good Corporate Governance Pada Badan Usaha Manufaktur, Perbankan, and Jasa Keuangan Lainnya. Bandung : Alfabeta

39. Zeitun, R. And Tian, G. G. 2007. Capital Structure and corporate performance-evidence from Jordan, Australasian Accounting Business and Finance Journal, 1(4). 